\title{
Diethylnitrosamine induces lung adenocarcinoma in FVB/N mouse
}

\author{
Zsolt Mervai, Krisztina Egedi, llona Kovalszky and Kornélia Baghy* (i)
}

\begin{abstract}
Background: Diethylnitrosamine is a well known carcinogen that induces cancers of various organs in mice and rats. Using FVB/N mouse strain, here we show that diethylnitrosamine induces primarily lung adenocarcinomas with modest tumor development in the liver, offering a new model to study chemical carcinogenesis in the lung.

Methods: Animals were exposed to a single high dose of diethylnitrosamine, and more than $70 \%$ of the mice developed lung cancer. To obtain a new transplantable tumor line, pieces of primary tumors were inoculated and maintained subcutaneously in the same mouse strain. We used immunohistochemistry to characterize the tumor for main lung adenocarcinoma markers. We searched for mutations in KRAS exon 2 and EGFR exon 19, 21 with Sanger sequencing. We also compared the normal lung tissue with the diethylnitrosamine induced primary adenocarcinoma, and with the subcutaneously maintained adenocarcinoma using Western blot technique for main cell cycle markers and to identify the main pathways.
\end{abstract}

Results: Primary and subcutaneous tumors express cytokeratin-7 and thyroid transcription factor-1, markers characteristic to lung adenocarcinoma. In addition, no mutations were found in the hot spot regions of KRAS and EGFR genes. We found high mTOR activation, but the level of p-Akt Ser473 and p-Akt Thr308 decreased in the tumorous samples.

Conclusions: We established a new lung adenocarcinoma model using FVB/N mouse strain and diethylnitrosamine. We believe that this new model system would be highly useful in lung cancer research.

Keywords: Lung cancer, NSCLC, Mouse model, Diethylnitrosamine, Tumorigenesis

\section{Background}

Cancer is the second leading cause of death nowadays $[1,2]$. Lung cancer is the most frequent tumor all over the world which claims the most life among other cancer types in Europe and in the United States [1, 2]. According to their phenotype and clinical behavior lung cancers are divided to two major types: small cell lung cancer (SCLC) and non-small cell lung cancer (NSCLC). NSCLC is the more common type of lung carcinomas [3]. In the US $85 \%$ of the lung cancers are NSCLC [3]. In the last decade adenocarcinomas became the dominant representative within NSCLC [4]. These NSCLCs express proteins such as cytokeratin-7 (CK7) and thyroid transcription factor-1 (TTF1) which are diagnostic markers of the tumor $[5,6]$.

\footnotetext{
* Correspondence: baghy.kornelia@med.semmelweis-univ.hu Department of Pathology and Experimental Cancer Research, Budapest, Hungary
}

(c) The Author(s). 2018 Open Access This article is distributed under the terms of the Creative Commons Attribution 4.0 International License (http://creativecommons.org/licenses/by/4.0/), which permits unrestricted use, distribution, and reproduction in any medium, provided you give appropriate credit to the original author(s) and the source, provide a link to the Creative Commons license, and indicate if changes were made. The Creative Commons Public Domain Dedication waiver (http://creativecommons.org/publicdomain/zero/1.0/) applies to the data made available in this article, unless otherwise stated. mors where the importance of driver mutations has been discovered. So far treatment options are guided by the KRAS and the epidermal growth factor receptor (EGFR) status as the majority of mutations can be detected on KRAS exon 2 and EGFR exon 19, 21 [7-10]. EGFR signaling activates downstream pathways such as Akt/mTOR and MEK/Erk which then promote cell proliferation [11].

Because of the high representation of adenocarcinoma and its relative great number of targetable mutations compared to other cancer types it is one of the best examined cancer [3]. For in vitro studies cell lines are available, but for in vivo experiments the opportunities are limited. Lung cancer is inducible in mouse with Jaaksiegte sheep retrovirus, but only in the immunocompromised strains [12]. Benzopyrene and 4-(methylnitrosamino)-1-(3-pyridyl)-1-butanone induced lung carcinogenesis is a known and described way to create lung tumors, but only in few 
strains [13]. A Cre-recombinase mediated model also exists [14]. Here we present another easy way to develop lung adenocarcinoma in $\mathrm{FVB} / \mathrm{N}$ mouse strain.

Diethylnitrosamine (DEN) is a well-known and widely used chemical compound to cause cancer in vivo [15]. The mechanism of action of DEN involves it's adduct formation potential. After it's bioactivation by CYP450 enzymes it transforms to be a strong alkylating agent that will form adducts in the DNA, which results in a direct carcinogen effect [16]. We injected FVB/N mice with one single dose of DEN. This lung carcinogen effect of DEN was described earlier in $\mathrm{A} / \mathrm{J}$ mouse strain [17]. A/J strain is susceptible to lung cancer and after DEN exposure they developed lung adenocarcinomas which were positive for KRAS mutation in the $80 \%$ of the cases [17].

FVB/N mouse strain has also high susceptibility for lung cancer [18]. An aging study with FVB/N strain published in the literature indicated that lung and liver cancer were the two most represented tumor types developed. At age 14 months $14 \%$ of the population had lung cancers, but there were no liver tumors. The former increased to $38 \%$ in the 24 months old population but only $6 \%$ had liver cancer. The population contained both males and females [18].

Our primary aim was to assess the lung cancer initiation potency of DEN in FVB/N strain and also determine the KRAS and EGFR status of the tumors which could later serve as a new model for NSCLC research. We wanted to compare the characteristics of DEN induced and spontaneously developed lung tumors by their markers and molecular status. We also aimed to determine the main signaling pathways driving tumor proliferation together with the status of the cell cycle.

\section{Methods}

\section{Animals and treatments}

All animal experiments were conducted according to the ethical standards of the Animal Health Care and Control Institute Csongrád County, Hungary. The protocol was approved by the Committee of the Animal Health Care and Control Institute Csongrád County, Hungary (permit No. XVI/03047-2/2008).

FVB/N mice were purchased from Charles Rivers. A total of 40 animals (20 male and 20 female) were utilized for carcinogenesis experiments. A single dose $(15 \mu \mathrm{g} / \mathrm{g}$ body weight) of DEN (N0258, Sigma-Aldrich, St. Louis, Missouri, US) was injected intraperitoneally at the age of 15 days. DEN concentration was chosen to be low enough to minimalize mutation occurrence and high enough for tumor formation within a year. A total of 14 mice served as age-matched untreated controls. Animals were terminated one year after DEN exposure by cervical dislocation in ether anesthesia. The body, lung and liver weight of mice were measured, and the number of macroscopically detectable tumors was recorded. Samples were fixed in $10 \%$ buffered formaldehyde and embedded in paraffin for histological analysis.

For generating subcutaneously maintained lung carcinoma, lung tumors were removed, cut into small pieces, washed in PBS and transplanted subcutaneously in another FVB/N mouse. The tumor was passaged when necessary. Samples were stored at $-70{ }^{\circ} \mathrm{C}$. DNA was isolated from the primary tumor and tumor from the 14th passage.

\section{Immunohistochemistry}

Formalin-fixed paraffin-embedded (FFPE) sections were dewaxed in xylene and ethanol then washed in distilled $\mathrm{H}_{2} \mathrm{O}$. Antigen retrieval was carried out with citrate buffer $(10 \mathrm{mM}$ citric acid, $0.05 \%$ Tween $20, \mathrm{pH}=6.0)$ in a pressure cooker for $20 \mathrm{~min}$. Slides were washed three times in phosphate buffered saline $+0.05 \%$ Tween 20 (PBST). Endogenous peroxidase block was applied for 10 min with $3 \% \mathrm{H}_{2} \mathrm{O}_{2}$. After another washing procedure $5 w / v \%$ bovine serum albumin (BSA)/PBS was used to block non-specific antibody binding sites. Primary antibodies were dissolved in $1 \mathrm{w} / \mathrm{v} \% \mathrm{BSA} /$ phosphate buffered saline (PBS) and applied for overnight at $4{ }^{\circ} \mathrm{C}$. Primary antibodies were rabbit monoclonal anti-TTF1 (ab76013, Abcam, Cambridge, UK, dilution: 1:50) and rabbit polyclonal anti-CK7 (HPA007272, Atlas antibodies, Stockholm, Sweden, dilution: 1:100). The next day PBST wash was applied for $5 \times 5$ minutes. Secondary antibody was horse-radish peroxidase (HRP) conjugated anti-rabbit antibody (P0448, Dako, Glostrup, Denmark) applied for $1 \mathrm{~h}$. After washing procedure signals were visualized with 3,3-diaminobenzidine tetrahydrochloride (DAB) substrate chromogen solution (Novolink Polymer Detection System, RE7150-K, Leica Biosystems, Wetzlar, Germany). Nuclei were stained by hematoxillin. The slides were scanned, and viewed with Pannoramic Viewer (3D Histech Ltd., Budapest, Hungary).

\section{Sanger sequencing \\ DNA isolation from frozen tissue and from FFPE sections}

Frozen tumorous tissue was homogenized in liquid nitrogen and suspended with $400 \mu \mathrm{l}$ lysis buffer $(0.2 \mathrm{M}$ $\mathrm{NaCl}, 0.02 \mathrm{M}$ EDTA, 0.04 M Tris and 0.5\% SDS) supplemented with $20 \mu \mathrm{l}$ Proteinase K $(10 \mathrm{mg} / \mathrm{ml}$, Roche, Basel, Switzerland) and $2 \mu \mathrm{l} \beta$-mercaptoethanol.

On FFPE sections, tumorous area was marked under light microscope. Next, slides were dewaxed, and then rinsed in acetone and alcohol. After drying, the marked tumorous areas were removed by a scalpel and incubated in Tris-EDTA (10 mM Tris, $1 \mathrm{mM}$ EDTA, $\mathrm{pH}=$ 7.4) buffer containing $2 \mathrm{mg} / \mathrm{ml}$ Proteinase $\mathrm{K}$ at $55{ }^{\circ} \mathrm{C}$ overnight with $300 \mathrm{rpm}$ shaking to remove proteins. 
The enzyme was heat-inactivated at $95{ }^{\circ} \mathrm{C}$ for $10 \mathrm{~min}$ followed by $15 \mathrm{~min}$ incubation on ice. Lysates were centrifuged at $13000 \mathrm{rpm}$ for $15 \mathrm{~min}$. The supernatants were kept and $50 \mu \mathrm{l}, 5 \mathrm{M} \mathrm{NaCl}$ was added and incubated for another $15 \mathrm{~min}$ on ice. After centrifugation with $13,000 \mathrm{rpm}$ for $10 \mathrm{~min}, 1 \mathrm{ml}$ of ice-cold ethanol was added to each supernatant to precipitate DNA. The samples were centrifuged with 13,000 rpm for $10 \mathrm{~min}$ and the pellets were dried out with Savant AES 1000 SpeedVac system (Thermo Fischer Scientific, Waltham, MA). Pellets were dissolved in $50 \mu \mathrm{l}$ TE buffer and DNA concentrations were measured with NanoDrop ND-1000 spectrophotometer (Thermo Fischer Scientific, Waltham, MA).

\section{Polymerase chain reaction (PCR)}

Primers designed for mouse EGFR exon 19, 21 and KRAS exon 2 are shown in Table 1.

Reactions were performed in a total volume of $20 \mu \mathrm{l}$. ImmoMix Red 2× (BIO-25002, Bioline, London, UK) reaction-mix was used for the PCR. Twenty pmol of forward and reverse primer (Integrated DNA Technologies, Coralville, IA), $\mathrm{MgCl}_{2}$ (BIO-37026, Bioline, London, UK) and 50 ng DNA was added to each reaction. Thermal cycle parameters were as follows: $95{ }^{\circ} \mathrm{C}$ initial denaturation for $10 \mathrm{~min}$ followed by 40 cycles of denaturation at $95{ }^{\circ} \mathrm{C}$ for $40 \mathrm{~s}$, annealing at appropriate temperature for $40 \mathrm{~s}\left(59{ }^{\circ} \mathrm{C}\right.$ for KRAS exon $2,56^{\circ} \mathrm{C}$ for EGFR exon 19 , $57{ }^{\circ} \mathrm{C}$ for EGFR exon 21 primers), elongation at $72{ }^{\circ} \mathrm{C}$ for $40 \mathrm{~s}$. PCR was carried out using Veriti 96 Well Thermal Cycler (Thermo Fischer Scientific, Waltham, MA). PCR products were checked on a $2 \%$ agarose gel by electrophoresis.

\section{Cycle sequencing and electrophoresis}

For PCR product clean-up, ExoSap (Cat. no.: 78201, Affymetrix, Cleveland, $\mathrm{OH}$ ) was applied following the instructions of the manufacturer. Cycle sequencing reactions were conducted using BigDye Terminator v3.1 Cycle Sequencing Kit (Cat. no.: 4337454, Thermo Fischer Scientific, Waltham, MA) as specified in the user guide. The subsequent cleaning step was performed with Nucleo-SEQ kit (Cat. no.: 740523, Macherey-Nagel, Düren, Germany) as described in the user manual. The samples were eluted in $20 \mu \mathrm{l}$

Table 1 Primer sequences

\begin{tabular}{ll}
\hline Gene & Primer sequence \\
\hline EGFR exon 19 forward & 5'-CTGGATCCCAGAAGGTGAGA-3' \\
EGFR exon 19 reverse & 5'-GGAAGCAAGATTGACCTTATGAA-3' \\
EGFR exon 21 forward & 5'-TTGGCAGCCAGGAATGTACT-3' \\
EGFR exon 21 reverse & 5'-GGCTGTCAGGAAAATGCTTC-3' \\
KRAS exon 2 forward & 5'-TGTAAGGCCTGCTGAAAATG-3' \\
KRAS exon 2 reverse & 5'-GCACGCAGACTGTAGAGCAG-3' \\
\hline
\end{tabular}

formamide and denatured at $95{ }^{\circ} \mathrm{C}$ for $1 \mathrm{~min}$. Capillary electrophoresis was carried out on a 3500 Series Genetic Analyzer (Thermo Fischer Scientific, Waltham, MA). Sequences were analyzed using BioEdit Sequence Alignment Editor (Ibis Biosciences, Carlsbad, CA).

\section{Western blot}

Frozen tissues were homogenized and suspended with lysis buffer (containing: $20 \mathrm{mM}$ Tris $\mathrm{pH}=7.5,150 \mathrm{mM}$ $\mathrm{NaCl}, 2 \mathrm{mM}$ EDTA, 0.05\% Triton X-100, 0.5\% Protease Inhibitor Cocktail (P8340, Sigma-Aldrich, St. Louis, MO), $2 \mathrm{mM} \mathrm{Na}_{3} \mathrm{VO}_{4}$ and $10 \mathrm{mM} \mathrm{NaF}$ ). Protein concentrations were measured by Bradford method. For normal lung and primary tumors, lysates of 5 different specimens were pooled to generate one sample, and 3 different samples were prepared. Pooled primary tumor samples were individually analyzed checking for diversity (Additional file 1: Fig. S1). The selected proteins displayed quite homogenous distribution proving the applicability of pooled samples later on (Additional file 1: Fig. S1). For subcutaneous tumors, 1 tumor sample was run in each experiment. Thirty $\mu$ g of total proteins were mixed with loading buffer containing $\beta$ mercaptoethanol and denatured at $99{ }^{\circ} \mathrm{C}$ for $5 \mathrm{~min}$. Denatured samples were loaded onto a $10 \%$ SDSpolyacrylamide gel and separated for $40 \mathrm{~min}$ at $200 \mathrm{~V}$. Proteins were transferred to a PVDF membrane with overnight blotting at $4{ }^{\circ} \mathrm{C}$ at constant $75 \mathrm{~mA}$. Blotting efficiency was checked by Ponceau staining. Blocking procedure was carried out with $5 \%$ non-fat dry milk dissolved in Tris-buffered saline (TBS) applied for $1 \mathrm{~h}$. Next, membranes were incubated overnight with primary antibodies. After washing with TBST (TBS + $0.05 \%$ Tween 20 ), appropriate secondary antibody dissolved in 1\% non-fat dry milk (TBS) was applied for $1 \mathrm{~h}$ at room temperature. After washing, immunoreactions were visualized using SuperSignal West Pico Chemiluminescent Substrate kit (Cat. no.: 34078, Thermo Fischer Scientific, Waltham, MA). Bands were detected with Kodak Image Station 4000MM (Kodak, Rochester, NY). Western blots were run in 3 independent experiments. Antibodies with their appropriate dilutions used for Western blots are shown in Table 2.

\section{Results}

Activity of DEN to induce lung cancer

We found DEN to be a potent lung carcinogen in the FVB/N mouse strain. Out of 39 mice, 28 developed macroscopic lung tumors. Six of them had multiple neoplasia (Table 3). The tumor prevalence between the genders showed only minor differences and no differences in lung mass was observed (Table 3). Histologically, tumors appeared to be papillary carcinomas, their morphology 
Table 2 Antibodies and their specifications

\begin{tabular}{|c|c|c|c|c|}
\hline Primary antibody & Manufacturer & Catalog number & Source & Dilution \\
\hline Akt & Cell Signaling Technology, Danvers, MA & $\# 4691$ & rabbit & 1:1000 \\
\hline p-Akt (Thr308) & Cell Signaling Technology & \#2965 & rabbit & $1: 1000$ \\
\hline p-Akt (Ser473) & Cell Signaling Technology & $\# 4058$ & rabbit & $1: 1000$ \\
\hline p-Erk 1/2 & Cell Signaling Technology & \#4370 & rabbit & $1: 1000$ \\
\hline p-GSK3 a/ $\beta$ & Cell Signaling Technology & \#9331 & rabbit & $1: 500$ \\
\hline p-S6 & Cell Signaling Technology & \#2211 & rabbit & $1: 1000$ \\
\hline CDK4 & Neomarkers, Fremont, California, US & \#MS-616 & mouse & $1: 250$ \\
\hline PCNA & Atlas antibodies, Stockholm, Sweden & HPA030522 & rabbit & $1: 1000$ \\
\hline $\mathrm{p}-\mathrm{Rb} \mathrm{S780}$ & Cell Signaling Technology & \#9307 & rabbit & $1: 250$ \\
\hline$\beta$-actin & Sigma-Aldrich, St. Louis, MO & A2228 & mouse & $1: 5000$ \\
\hline
\end{tabular}

was very similar to that observed in human disease. Most tumors were moderately or well-differentiated, a few showed poorly differentiated appearance. Multiple neoplasias often had mixed phenotype.

Out of 14 untreated control only two mice developed spontaneous lung adenocarcinoma (Table 4). Only males were observed in the control group because there was no significant difference in the lung tumor development between the males and females in the literature [18]. The two tumors appeared to be poorly differentiated papillary carcinomas; however the low number prevents its comparison to DEN-induced tumors.

\section{Histochemical markers of lung adenocarcinoma}

With immunostaining all the 28 tumorous tissues showed high level of CK7 and TTF1 expression which confirmed the lung adenocarcinoma diagnosis (Fig. 1). The spontaneous lung tumors also showed CK7 and TTF1 positivity.

\section{KRAS and EGFR sequencing}

KRAS and EGFR mutation hot spots were analyzed in all tumorous samples including spontaneous tumors. No mutations were found in KRAS exon 2 and in EGFR exons 19 and 21 (Fig. 2).

\section{Alterations in signaling pathways}

Akt/mTOR, ERK pathways and G1/S restriction point were analyzed by Western blot technique. We compared normal FVB/N lung tissue with the DEN induced primary adenocarcinoma and with the subcutaneously

Table 3 Tumor prevalence in FVB/N mice induced by DEN

\begin{tabular}{lllll}
\hline Gender & Total No. & $\begin{array}{l}\text { Animals with } \\
\text { macroscopic } \\
\text { lung tumors }\end{array}$ & $\begin{array}{l}\text { Average } \\
\text { lung mass }\end{array}$ & $\begin{array}{l}\text { Average lung } \\
\text { mass/ body mass (\%) }\end{array}$ \\
\hline Male & 19 & 15 & $0.24 \mathrm{~g}$ & 0.78 \\
Female & 20 & 13 & $0.23 \mathrm{~g}$ & 0.78 \\
\hline
\end{tabular}

maintained lung tumor. The amount of Akt phosphorylated at Thr308 and Ser473 significantly decreased in the subcutaneously maintained sample, and p-Akt Thr308 in the DEN induced primary tumor showed similar tendency compared to the normal lung tissue, whereas Ser473 remained unchanged in the primary tumor. On the other hand p-S6 increased $\sim 5$-fold in both tumor samples. While p-Erk $1 / 2$ in the primary tumor did not differ from the control, it was greatly increased (20\% and $80 \%$ respectively) in the subcutaneously maintained tumor compared to the normal tissue. The phosphorylation of GSK3 $\beta$ decreased in the subcutaneous adenocarcinoma, while it remained unchanged in the primary tumor (Fig. 3).

Regarding cell cycle regulation, the level of CDK4 responsible for retinoblastoma phosphorylation in G1-S transition, increased with $\sim 4$-fold in both tumor samples. Phospho-Rb S780 increased significantly in the primary tumor, but interestingly decreased in the subcutaneous tumor. The S-phase marker PCNA showed a remarkable $\sim 18$-fold elevation in the primary tumor and $\sim 25$-fold in the subcutaneous tumor compared to the normal tissue indicating their increased proliferation. (Fig. 4).

\section{Discussion}

DEN is a commonly used agent to induce liver cancer $[15,19]$. In addition, some literature data indicates that chemical carcinogens, such as DEN, can be a potent lung carcinogen in strains where the frequency of the lung tumors was already higher than any other cancer $[13,14,17]$. In the literature DEN was used in a concentration of $50 \mathrm{mg} / \mathrm{kg}$ to induce lung tumor and only

Table 4 Tumor prevalence in control, untreated FVB/N mice

\begin{tabular}{llll}
\hline Total No. & $\begin{array}{l}\text { Animals with } \\
\text { macroscopic } \\
\text { lung tumors }\end{array}$ & Average lung mass & $\begin{array}{l}\text { Average lung } \\
\text { mass/ body } \\
\text { mass (\%) }\end{array}$ \\
\hline 14 & 2 & $0.15 \mathrm{~g}$ & 0.5 \\
\hline
\end{tabular}



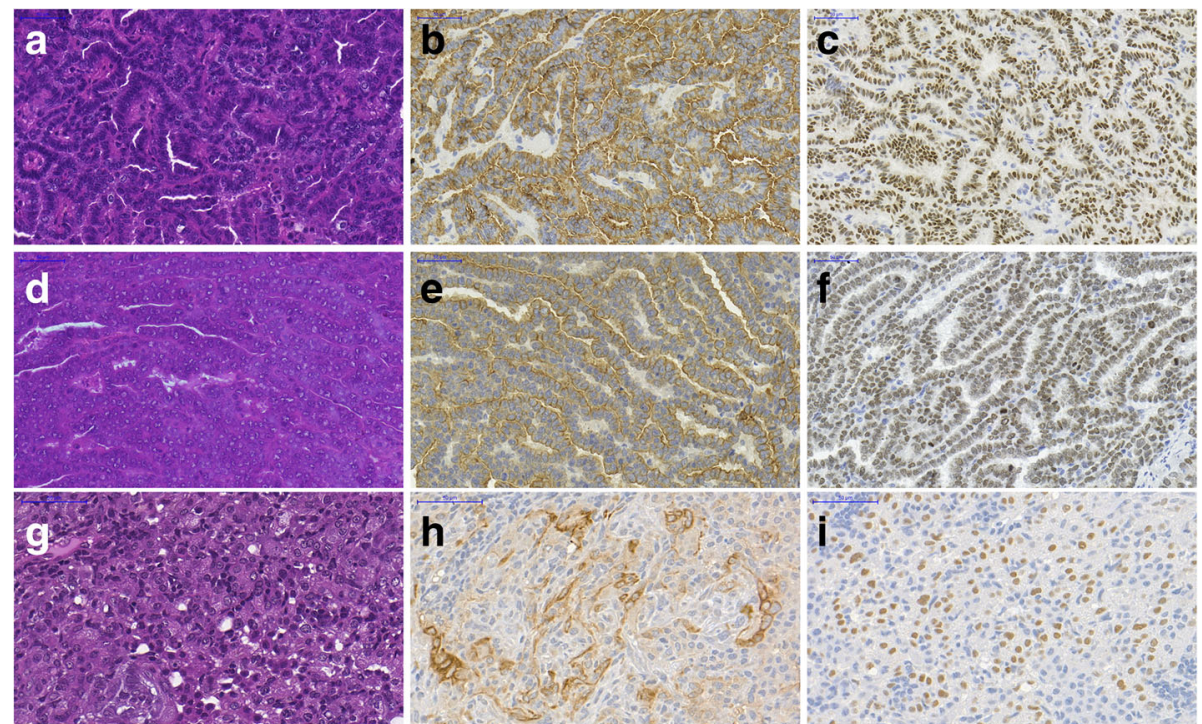

Fig. 1 Histological analysis of primary, subcutaneous and spontaneous lung adenocarcinoma. (a-c) Primary tumor; (d-f) Subcutaneous tumor; ( $\mathbf{g}-\mathbf{i}$ ) Spontaneous tumor, (a,d,g) Hematoxylin and eosin staining. Immunostaining of cytokeratin-7 (b,e,h) and TTF1 (c,f,i). Primary and subcutaneous tumors are from different animals. Scale bar $=50 \mu \mathrm{m}$

KRAS was analyzed, which was found to be $80 \% \mathrm{mu}-$ tated. We applied a single dose of $15 \mu \mathrm{g} / \mathrm{g}$ intraperitoneally, hypothetically low enough to minimize mutation occurrence and ideally avoid mutations in KRAS and EGFR genes. In our cases neither primary nor subcutaneously maintained tumors harbored mutations in EGFR exon 19, 21 or KRAS exon 2. These data may indicate a dose dependent mutation forming effect, but a more probable hypothesis is that the $\mathrm{A} / \mathrm{J}$ mouse strain is more susceptible to lung cancer with mutant KRAS, simply because of it has different genetic background compared to that of $\mathrm{FVB} / \mathrm{N}$. In human adenocarcinomas the frequency of EGFR mutations is estimated between 15 and $45 \%$, whereas KRAS mutation was detected in $20 \%$ of the cases depending on the geographical region [20]. However, our model could represent the portion of human adenocarcinomas negative for KRAS and EGFR mutations.

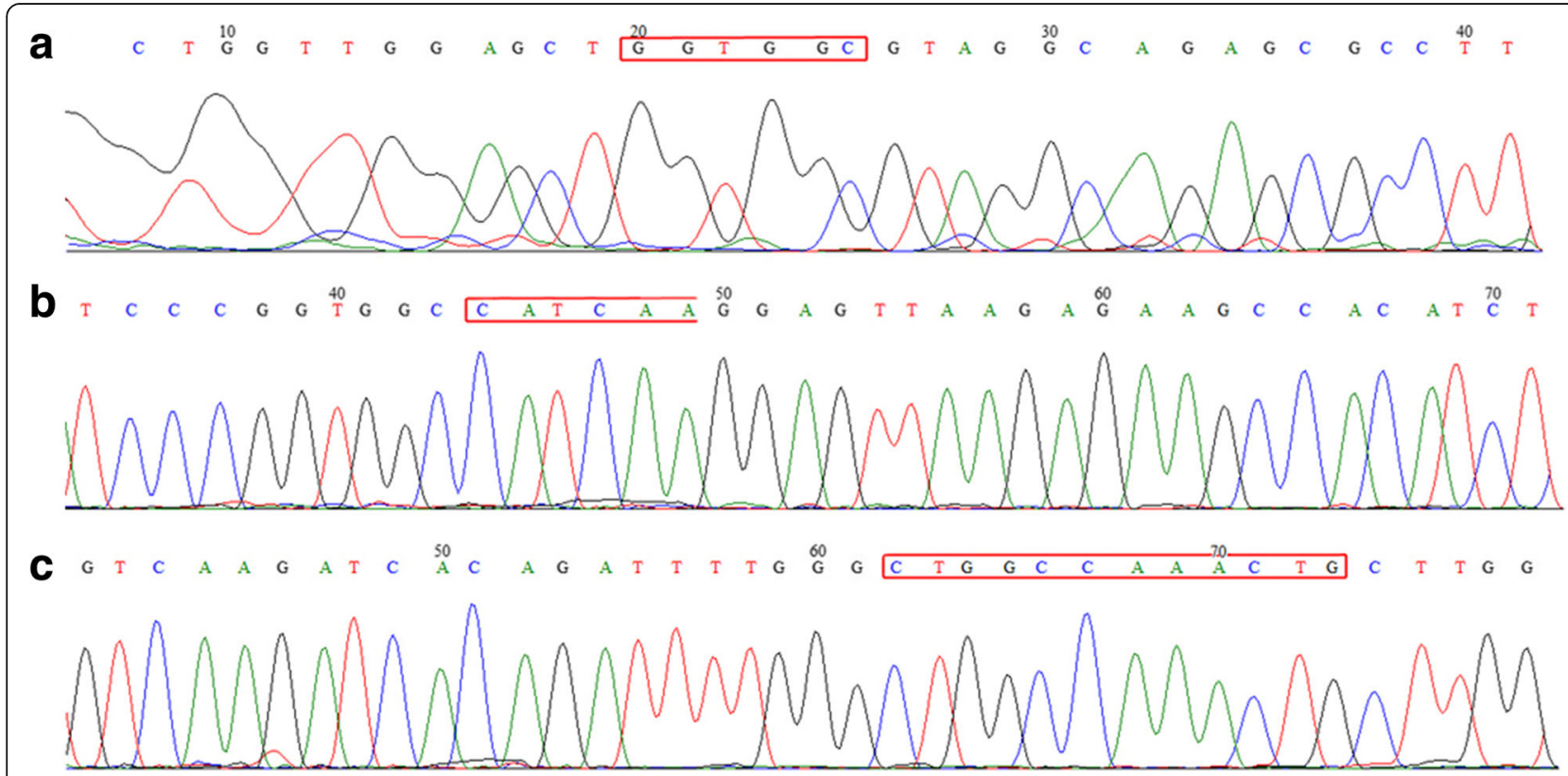

Fig. 2 Mutation analysis by Sanger sequencing. (a) KRAS sequence, (b) EGFR exon 19 sequence, (c) EGFR exon 21 sequence; Regions of potential mutations are marked in the sequences 


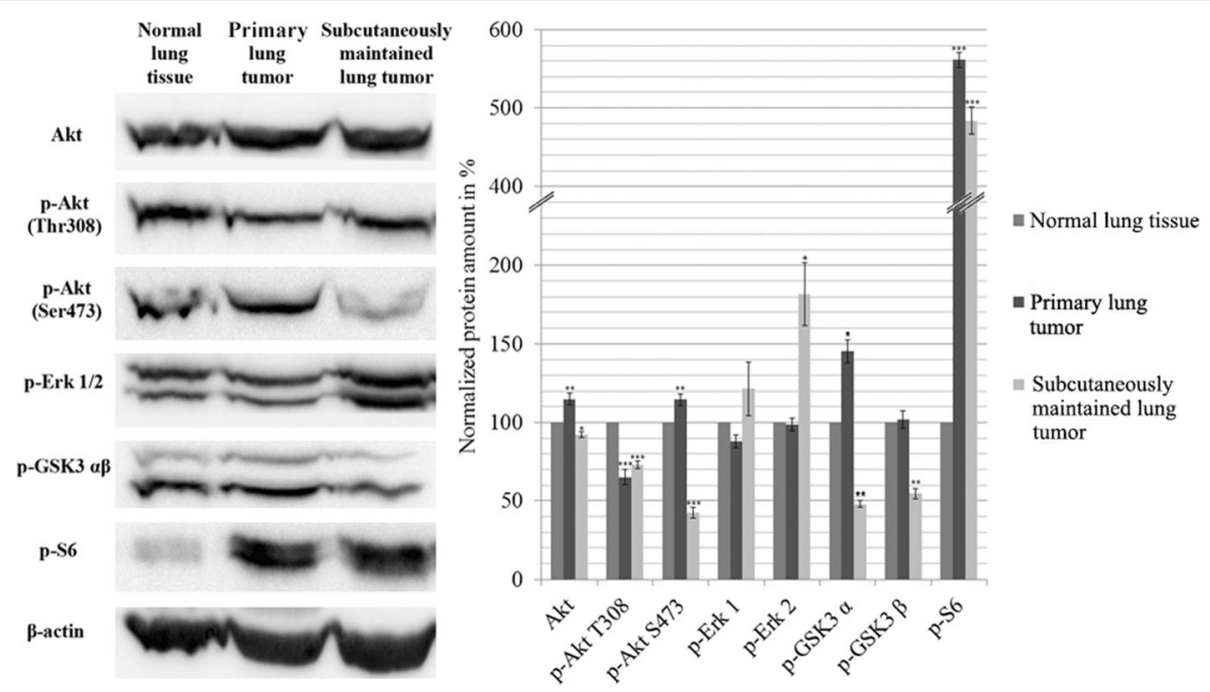

Fig. 3 Western blot analysis of the main signaling pathways. The data are the mean \pm SD of 3 experiments, ${ }^{*} P<0.05 ;{ }^{* *} P<0.01$ and ${ }^{* * *} P<0.001$. Blots are separate images

FVB/N mice is a well-known and described mouse strain, which is more susceptible to develop spontaneous lung cancer than any other tumor and the ratio of liver tumors are lower than in other strains [18]. This susceptibility can explain why DEN induced tumors predominantly in the lung, and very few in the liver until the 1st year endpoint. DEN might speed up the already existing susceptibility for lung cancer formation which theory is in harmony with other literatures [14]. Regarding morphology, tumors in our model appeared to be papillary carcinomas, all TTF-1 and cytokeratin-7 positive analogous to human lung cancers.

The increased p-S6 indicates a more active mTOR signaling which leads to cell proliferation [21]. Interestingly the amount of both p-Akt is decreased in the subcutaneously maintained tumor and a reduction can also be seen in the level of p-Akt Ser473 in the primary tumor, as well. Phosphorylation of Erk1/2 increased in the subcutaneous tumor which can be one of the mechanism that results in active mTOR pathway [22]. The decreased amount of p-GSK3 correlates well with the low level of p-Akt in all the samples.

The proliferation stimuli results in a constantly working cell cycle which can be seen in the two tumorous samples. CDK4 and the S phase marker PCNA are greatly increased in both tumors compared to the normal lung sample $[23,24]$. Increased $\mathrm{p}-\mathrm{Rb} \mathrm{S} 780$ in the primary tumor also confirms this, but interestingly it decreased in the subcutaneous tumor. This could be explained by the hyperphosphorylation of $\mathrm{Rb}$ which can lead to its degradation [25]. It is also possible that Rb protein was lost due to deleterious mutation [26].

These results prove that the FVB/N mouse strain can be used for lung cancer experiments, because chemical carcinogens speed-up its already accelerated lung tumorigenesis resulting adenocarcinomas. In addition, our model is unique as it can better represent human

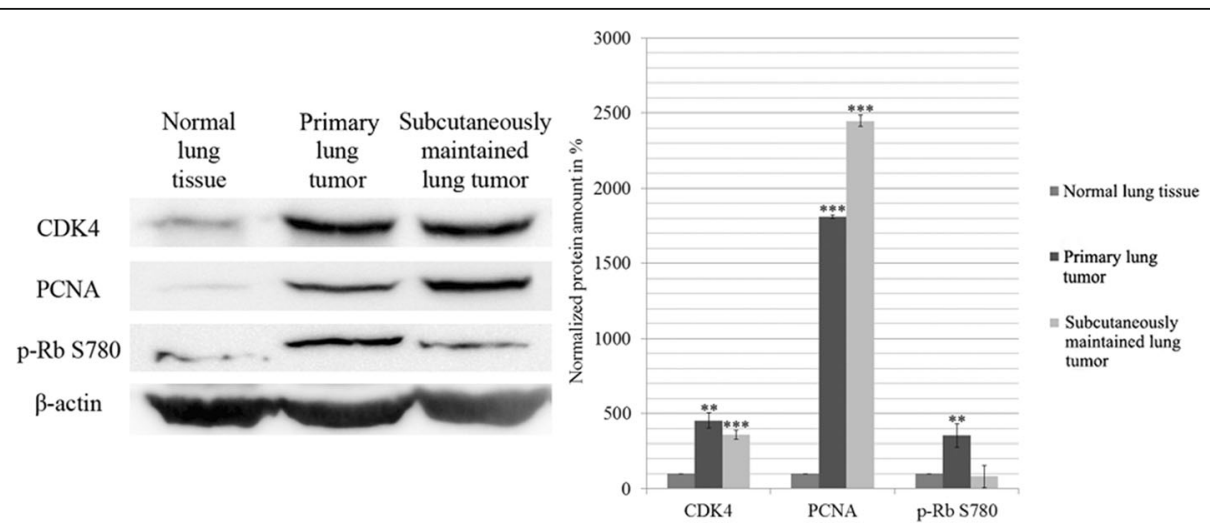

Fig. 4 Western blot analysis of the main cell cycle proteins. The data are the mean \pm SD of 3 experiments, ${ }^{*} P<0.05 ;{ }^{* *} P<0.01$ and ${ }^{* * *} P<0.001$. Blots are separate images 
lung adenocarcinoma cases with no common KRAS and EGFR mutations. Thus we believe that this wellcharacterized model with unraveled signaling pathways has a value in both academic and practical use.

\section{Conclusions}

We found diethylnitrosamine as a potent chemical substance to induce lung adenocarcinoma in $\mathrm{FVB} / \mathrm{N}$ mouse strain. The tumor was positive for CK7 and TTF1. We found no mutations in KRAS exon 2 and EGFR exon 19 and 21. The proliferation of the tumors is driven by the MAPK and mTOR pathways ending up with the stimulation of cell cycle at the G1/S restriction point. The model could be a useful tool in lung cancer research targeting KRAS and EGFR negative tumors.

\section{Additional file}

Additional file 1: Figure S1. Western blot analysis of pooled tumor samples. (A) Image of Western blot run loaded with individual primary tumor samples. (B-C) Quantification of various protein amounts. (D) Average of protein levels measured in individual tumors (data are expressed as mean \pm SD). (JPEG $522 \mathrm{~kb}$ )

\begin{abstract}
Abbreviations
BSA: bovine serum albumin; CDK: cyclin-dependent kinase; CK7: cytokeratin7; DAB: 3,3-diaminobenzidine; DEN: diethylnitrosamine; EGFR: epidermal growth factor receptor; FFPE: Formalin-fixed paraffin-embedded; HRP: horseradish peroxidase; KRAS: Kirsten rat sarcoma; mTOR: mammalian target of rapamycin; NSCLC: non-small cell lung cancer; PBS: phosphate-buffered saline; PCNA: Proliferating cell nuclear antigen; PCR: polymerase chain reaction; $\mathrm{Rb}$ : retinoblastoma; $\mathrm{SCLC}$ : small cell lung cancer; TBS: tris-buffered saline; TTF1: thyroid transcription factor-1
\end{abstract}

\section{Acknowledgements}

The authors would like to thank András Sztodola for his valuable help in the animal nursing.

\section{Funding}

This work was supported by Hungarian Research Fund (OTKA) (No. 100904 to Ilona Kovalszky; and No. 105763 to Kornélia Baghy). The funding body had no role in the design of the study and collection, analysis, and interpretation of data and in writing the manuscript.

\section{Availability of data and materials}

The datasets used and/or analyzed during the current study available from the corresponding author on reasonable request.

\section{Authors' contributions}

Zsolt Mervai conducted most of the experiments and drafted the manuscript. Krisztina Egedi performed the Sanger sequencing. Ilona Kovalszky and Kornélia Baghy designed the study and drafted the manuscript. All authors read and approved the final manuscript.

\section{Competing interest}

The authors declare that they have no competing interests.

\section{Ethics approval}

All animal experiments were conducted according to the ethical standards of the Animal Health Care and Control Institute Csongrád County, Hungary. The protocol was approved by the Committee of the Animal Health Care and Control Institute Csongrád County, Hungary (permit No. XVI/03047-2/2008).

\section{Consent for publication}

Not applicable.

\section{Publisher's Note}

Springer Nature remains neutral with regard to jurisdictional claims in published maps and institutional affiliations.

Received: 3 November 2016 Accepted: 29 January 2018

Published online: 07 February 2018

\section{References}

1. Ferlay J, Steliarova-Foucher E, Lortet-Tieulent J, Rosso S, Coebergh JW, Comber H, Forman D, Bray F. Cancer incidence and mortality patterns in Europe: estimates for 40 countries in 2012. Eur J Cancer. 2013;49(6):1374-403.

2. Siegel R, Ma J, Zou Z, Jemal A. Cancer statistics, 2014. CA Cancer J Clin. 2014;64(1):9-29.

3. Molina JR, Yang P, Cassivi SD, Schild SE, Adjei AA. Non-small cell lung cancer: epidemiology, risk factors, treatment, and survivorship. Mayo Clin Proc. 2008;83(5):584-94.

4. Subramanian J, Govindan R. Lung cancer in never smokers: a review. Journal of clinical oncology : official journal of the American Society of Clinical Oncology. 2007;25(5):561-70.

5. Su YC, Hsu YC, Chai CY. Role of TTF-1, CK20, and CK7 immunohistochemistry for diagnosis of primary and secondary lung adenocarcinoma. Kaohsiung J Med Sci. 2006;22(1):14-9.

6. Cai YC, Banner B, Glickman J, Odze RD. Cytokeratin 7 and 20 and thyroid transcription factor 1 can help distinguish pulmonary from gastrointestinal carcinoid and pancreatic endocrine tumors. Hum Pathol. 2001;32(10):1087-93.

7. Lynch TJ, Bell DW, Sordella R, Gurubhagavatula S, Okimoto RA, Brannigan BW, Harris PL, Haserlat SM, Supko JG, Haluska FG, et al. Activating mutations in the epidermal growth factor receptor underlying responsiveness of nonsmall-cell lung cancer to gefitinib. N Engl J Med. 2004;350(21):2129-39.

8. Paez JG, Janne PA, Lee JC, Tracy S, Greulich H, Gabriel S, Herman P, Kaye FJ, Lindeman N, Boggon TJ, et al. EGFR mutations in lung cancer: correlation with clinical response to gefitinib therapy. Science. 2004; 304(5676):1497-500.

9. Riely GJ, Kris MG, Rosenbaum D, Marks J, Li A, Chitale DA, Nafa K, Riedel ER, Hsu M, Pao W, et al. Frequency and distinctive spectrum of KRAS mutations in never smokers with lung adenocarcinoma. Clinical cancer research : an official journal of the American Association for Cancer Research. 2008;14(18):5731-4.

10. Jang TW, Oak CH, Chang HK, Suo SJ, Jung MH. EGFR and KRAS mutations in patients with adenocarcinoma of the lung. Korean J Intern Med. 2009;24(1):48-54.

11. Ladanyi M, Pao W. Lung adenocarcinoma: guiding EGFR-targeted therapy and beyond. Mod Pathol. 2008;21(Suppl 2):S16-22.

12. Wootton $\mathrm{SK}$, Halbert $\mathrm{CL}$, Miller $\mathrm{AD}$. Sheep retrovirus structural protein induces lung tumours. Nature. 2005;434(7035):904-7

13. Hecht SS, Isaacs S, Trushin N. Lung tumor induction in a/J mice by the tobacco smoke carcinogens 4-(methylnitrosamino)-1-(3-pyridyl)-1-butanone and benzo[a]pyrene: a potentially useful model for evaluation of chemopreventive agents. Carcinogenesis. 1994;15(12):2721-5.

14. Meuwissen R, Berns A. Mouse models for human lung cancer. Genes Dev. 2005;19(6):643-64

15. Kushida M, Kamendulis LM, Peat TJ, Klaunig JE. Dose-related induction of hepatic preneoplastic lesions by diethylnitrosamine in C57BL/6 mice. Toxicol Pathol. 2011;39(5):776-86.

16. Verna L, Whysner J, Williams GM. N-nitrosodiethylamine mechanistic data and risk assessment: bioactivation, DNA-adduct formation, mutagenicity, and tumor initiation. Pharmacol Ther. 1996;71(1-2):57-81.

17. You M, Wang Y, Lineen AM, Gunning WT, Stoner GD, Anderson MW. Mutagenesis of the K-ras protooncogene in mouse lung tumors induced by $\mathrm{N}$-ethyl-N-nitrosourea or $\mathrm{N}$-nitrosodiethylamine. Carcinogenesis. 1992;13(9):1583-6.

18. Mahler JF, Stokes W, Mann PC, Takaoka M, Maronpot RR. Spontaneous lesions in aging FVB/N mice. Toxicol Pathol. 1996;24(6):710-6.

19. Goldfarb S, Pugh TD, Koen H, He YZ. Preneoplastic and neoplastic progression during hepatocarcinogenesis in mice injected with diethylnitrosamine in infancy. Environ Health Perspect. 1983;50:149-61.

20. Arrieta O, Cardona AF, Martin C, Mas-Lopez L, Corrales-Rodriguez L, Bramuglia G, Castillo-Fernandez O, Meyerson M, Amieva-Rivera E, Campos-Parra AD, et al. Updated frequency of EGFR and KRAS mutations in NonSmall-cell lung cancer in Latin America the Latin-American consortium for the investigation of lung cancer (CLICaP). J Thorac Oncol. 2015;10(5):838-43. 
21. Fingar DC, Richardson CJ, Tee AR, Cheatham L, Tsou C, Blenis J. mTOR controls cell cycle progression through its cell growth effectors S6K and $4 \mathrm{E}-\mathrm{BP} 1 /$ eukaryotic translation initiation factor $4 \mathrm{E}$. Mol Cell Biol. 2004;24(1):200-16.

22. Mendoza MC, Er EE, Blenis J. The Ras-ERK and PI3K-mTOR pathways: crosstalk and compensation. Trends Biochem Sci. 2011;36(6):320-8.

23. Foster DA, Yellen P, Xu L, Saqcena M. Regulation of G1 cell cycle progression: distinguishing the restriction point from a nutrient-sensing cell growth checkpoint(s). Genes Cancer. 2010;1(11):1124-31.

24. Landberg G, Roos G. Antibodies to proliferating cell nuclear antigen as S-phase probes in flow cytometric cell cycle analysis. Cancer Res. 1991; 51(17):4570-4.

25. Ma D, Zhou P, Harbour JW. Distinct mechanisms for regulating the tumor suppressor and antiapoptotic functions of Rb. J Biol Chem. 2003;278(21): 19358-66.

26. Giacinti C, Giordano A. RB and cell cycle progression. Oncogene. 2006; 25(38):5220-7.

Submit your next manuscript to BioMed Central and we will help you at every step:

- We accept pre-submission inquiries

- Our selector tool helps you to find the most relevant journal

- We provide round the clock customer support

- Convenient online submission

- Thorough peer review

- Inclusion in PubMed and all major indexing services

- Maximum visibility for your research

Submit your manuscript at www.biomedcentral.com/submit 